\title{
The Fundamental Thought and Practice of College Construction of Study Style
}

\author{
Hui Song \\ School of Automobile and Transportation Qingdao \\ Technological University \\ Shandong, 266520, P.R. China \\ songhuiapple1981@163.com
}

\author{
Fengyuan Wang", Lixin Liu \\ School of Automobile and Transportation Qingdao \\ Technological University \\ Shandong, 266520, P.R. China \\ fy58wang@qtech.edu.cn \\ liulixin@qtech.edu.cn
}

\begin{abstract}
Construction of Study Style is the fundamental guarantee to improve the quality of education and teaching for the existence and development of universities. It is an important indication to measure the education level of a university. Some new methods and new ideas to improve the construction quality were studied with some examples of School of Automobile and Transportation of Qingdao Technological University. The roles of different staff in the school were designed to carry out the construction task. Some results were presented to show the efficiency and possibility in the fulfillment of the measures.
\end{abstract}

Keywords-component; construction of study style; thought; practice; School fulfillment

\section{INTRODUCTION}

Study style is an overall performance of student in learning objective, motivation, attitude, spirit, discipline, method, academic score and other aspects under the guideline of life and values philosophy. Construction of Study Style (CSS in short) is the fundamental guarantee to improve the quality of education and teaching for the existence and development of colleges and universities. It's an important symbol to measure the level of university education. A good study style is the precious wealth of the school to show the importance of learning ability, thought quality and comprehensive quality for the basis of student cultivation [1,2]. It's necessary to explore new ideas, research new ways from all aspects of the study style construction process management and goals to guide, improve the quality of the college construction of study style. Some typical measures were taken to improve the quality of construction of study style in School of Automobile and Transportation (SAT in short) of Qingdao Technological University with the aid of leading role in university and college.

\section{THE THOUGHT AND PRACTICE ON CSS}

CSS is long-term system engineering. It is a key project to improve the quality of teaching. As a result, the college must form a good ethos of full participation style. This includes that the institute leaders lead CSS, the professional directors guide CSS, the tutors push forward CSS, the class teachers carry out CSS, specialty teachers influence CSS, students dominate CSS. A concerted effort has to be promoted in construction work.

\section{A. School Leaders Leading CSS}

CSS leader team should be established to take the dean as the leader, at the same time, take the party secretary and deputy secretary, the league secretary and instructors as group members to strengthen CSS. In each semester, CSS should be included in the school work plan, and a special meeting related to the research and analysis of the problems in CSS should be convened. Furthermore, the specific measures are proposed to implement the objective of CSS by combining with the discussion and the fact. Such as, School of Automobile and Transportation formulate and implement the contact system between teachers and students, which has achieved outstanding results. At different phases in each semester, the supervisors, persons in charge, teachers and students should carry on the discussion in which all aspects of students are involved .For example, monitor, league secretary, commissary in charge of studies, the best and worst students in class, "four trapped life" students (including economic poverty, mental confusion, learning difficulties, employment difficulties) etc. We are willing to understand the students' problems and demands in the learning process, and timely feed them back to the related department, and then take efficient measures to solve difficulties, strive for dialogue to resolve practical problems that exist in the students and try our best to create a platform for students' talent growth.

\section{B. Professional Directors Guiding CSS}

Professional directors should take an active part in students' trainings. There are many ways to do this: For example, giving regular professional reports, starting the freshmen' s professional educations when they enter school to stimulate their interests in learning professional and cultivate students' professional consciousness. Professional director should take teaching construction as their main working goal, make efforts to cultivate teachers' good teaching style, improve teachers' professionalism. Professional directors take advantage of abundant qualified teachers and doctors in our college; carry out "doctors and students face to face" seminars and other activities, to help students understand the professional learning. Professional directors invite the enterprise' $\mathrm{s}$ professionals to give lectures, to improve students' practical ability, to stimulate students' creative thinking and to encourage students' creative spirit. All the reports content should be archived in 
the form of files and pictures. The CSS group checks it regularly.

\section{Tutors Supervising CSS}

The tutors are the backbone to carry out the ideological and political education. They are organizers, practitioners and mentors for the university student daily political education and management work. Therefore, the tutors play an important role in urging students CSS. Tutors must firmly insist on CSS as the center, regularly go deep into student dormitory and classroom, strengthen communication with students, and usually find the problem students to carry on the conversation.

Tutors should analyze the student's grades, and through the vertical and horizontal comparison, find out insufficient parts of student grades, actively put forward improvement measures to improve students' grades; tutors should organize all kinds of thematic education activity, learning experience exchange meeting, postgraduate experience exchange meeting, simulation learning activities such as English test of CET-4 and CET-6, computer test of level 2; Tutors should fully play the role of campus network, integrate of cyber source. Tutors should grasp the Communist Party building and promote the study style. Strengthening the students' party building, is the inevitable requirement to promote CSS, is the need of the student's comprehensive growth [3].

\section{Class Teachers Carrying Out CSS}

Class teachers are the implementation of CSS. They must be a model of virtue for students and be a model of learning. Class teachers should take class CSS as a top priority of class work, grasp the class style, set up study style, pay highly attention to class CSS. In each semester, Class teachers should establish specific measures of CSS according to the actual class conditions in the work plans.

Class teachers should organize and guide the class to carry out activities for creating a good style of study class. Class teachers should undertake the guidance of education and learning methods in student learning purpose and enamoring major. Taking learning as the center, and taking comprehensive quality and ability training as the goal, seriously grasps the student education of learning objective, learning attitude and learning methods, systematically organizes academic activities and learning competitions, and guides the students to participant science and technology activities in improving students' comprehensive quality and creative ability.

Class teachers should regularly convene class meeting with CSS as the subject. On the summary meeting of CSS, class teachers should make the detailed analysis on the aspects of students phase learning, students' mentality and class activities. Fully play the incentive function of priority rating, scholarship evaluation system; class teachers should grasp class CSS by combining the power of students, parents and lecturers.

\section{E. Specialty Teachers Influencing CSS}

The key of the CSS is teaching style. Specialty teachers can influence and educate students by dedications, being rigorous with teaching, being never tired of teaching students and being a model of virtue for students. Every subject teacher is the guide of CSS. They should influence and motivate students with the noble professional ethics, favorable images, consummate skills and erudite knowledge. All in all, teachers should fully exert the functions of exampling to become good culturists which cultivate good study style of students.

In the process of CSS, teachers can motivate the students' interests and passions of studying by introducing the effects and significances of learning the courses to perfecting personal knowledge, quality developments and professional careers. So the students can consciously concentrate on learning. At first, teachers should manage the students' learning processes strictly and point out the students' problems in classroom discipline and learning pattern to help students establish the directions of learning. Then teachers should be acquainted with students' knowledge bases, teach students in accordance with their aptitude, draft teaching programs fitted for all students and adopt flexible methods, to mobilize the enthusiasm of the students, to encourage the students creative thinking, to create autonomous, cooperative, groping learning atmosphere, to improve the efficiency of classroom teaching. In addition, teachers should have a strong sense of imparting knowledge and educating students, not simply impart knowledge, but emphasize the learning methods, to cultivate students' interest in learning, coach students patiently and take corresponding measures according to different students' learning situations. Finally, teachers should strictly assess all students, establish a diversified evaluation system, exert the encouraging and leading effects of assessment on CSS, promote the formation of class correct learning consensuses and enhance each student's initiatives [4].

\section{F. $\quad$ Students Dominating CSS}

Student is the leading role of CSS, because in ideas and concepts the correct understanding of the formation of good learning atmosphere is each student's own responsibility. Therefore, school should exert students' master consciousnesses in the process of CSS, fully mobilize students' enthusiasms of creating fine CSS, encourage students to forwardly organize each project of the fine CSS, to forwardly organize science and technology innovation activities, to forwardly make the evaluation of teachers, to forwardly communicate with the school leaders, counselors, class teachers and specialty teachers, so the students can truly become the master of CSS. School of Automobile and Transportation formulate and implement evaluation system between teachers and students, by which in each grade of each professional some students who have strong sense of responsibilities and excellent achievements can be choose to evaluate teachers' teaching from all aspects. The system can objectively and really reflect the actual situation of teachers' teaching, let students truly participate in the CSS and dominate the CSS. The final result is to improve the effects and qualities of the teaching. 


\section{THE EFFECTIVENESS ANALYSIS OF CSS}

In recent years, School of Automobile and Transportation have gradually improved the quality of CSS by managing the processes of CSS and guiding the directions, and also by a good ethos of full participation style.

\section{A. The Postgraduate Rate Increasing}

Recently, fine study style motivates student passion of taking part in the entrance exams for postgraduate schools. School of Automobile and Transportation have basically maintained a higher postgraduate enrollment rate and have been named the outstanding college of post-graduation. The graduate student entrance examination is not only a vital employment channel, but also a basic channel for the excellent students. School always makes the pass rate of postgraduate throughout the process of teaching projects and managements. The school and teachers play a significant role in leading thoughts, coaching the professional knowledge, solving the difficulties in lives and dredging the mood of students.

\section{B. The Improvements of Practical Manipulative Ability}

Students' practical manipulative ability had been gradually improved to have the enthusiasm of participating in the technological innovation activities. Students take the Automobile Science and Technology Festival and the construction of college students' science and technology innovative and experimental area in Shandong province as platforms. And students have made large progresses year by year in the FSAE and NAC-Trans. Science and technology innovation activities attract the attention of students' professional learning. Many students spend the time after class on the thinking and practices of science and technology innovation activities. This can improve students' basic learning and the passion of professional learning.

\section{The Improvements of Comprehensive Quality}

By the CSS and constant innovation practice, students possess aggressive learning consciousnesses, rational clear learning goal orientations, simple and practical professional learning spirits, healthy and upward consciousnesses of being faithful person and enthusiastic and confident psychological diathesis. School makes the mission aimed at cultivating all-round developing talents throughout the construction process, such as combining the system norm with carrying out activities, focusing on promoting the healthy growth of students, taking a number of measures from the education and guidance, management services and others. All the periods emphasize the leading effects of teaching style, the agglomerate effects of class studying atmosphere and the driving effects of dormitory atmosphere. School carries out the class construction work deeply in a fine study style. School always lays stress on standardizing academic motivation mechanism. It can exert the leading effects of study model and form the competitive and advocating honor atmosphere.

\section{The Notable Effectiveness of the Developments and Reformations of the Subject}

SAT owns five professions, one of them is characteristic profession of Shandong province, and two of them are upgraded to scholastic characteristic profession. In addition, one provincial excellent teaching team, two provincial excellent course groups, ten provincial excellent courses and one scholastic excellent course group including six scholastic excellent courses were built up to improve the quality of teaching. Excellent course group covers the vital courses of all the professions in school. In order to realize that the efficient teaching style promote an excellent study style.

\section{CONCLUSIONS}

CSS concerns all the aspects of student lives. Nearly all students' projects in school are related to CSS. Therefore, the school must begin from the basic work, such as to promote the class atmosphere from the dormitory atmosphere, to promote the study style from the class atmosphere. Thus all the students fully participate in the CCS to enhance the goal vectoring, strengthen the process of management, make the study atmosphere strongly, increase the study power and promote the students CCS unconsciously. The managements of students study style concern their immediate interests. Its smooth launching is the guarantee to maintain a formal teaching system.

\section{ACKNOWLEDGMENT}

This work is sponsored by Teaching Reform Project of Shandong Provincial Education Branch (No. 2012285)

\section{REFERENCES}

[1] Botao Li. The investigations of the situations of study style in colleges[J]. Journal of Yangtze University (Social Sciences), 2009. 32(4): 320-321.

[2] Baokui Han. The discussion of campus culture and construction of study style among colleges [J]. Studies in Ideological Education , 2009, (6).

[3] Yang Yi. The current effects of construction of study style of college students[J]. Journal of Inner Mongolia Agricultural University (Social Sciences), 2009. 11(2):188-189.

[4] Xu Wei. The researches of construction of study style of college students and the countermeasures [J]. Journal of Qing Hai Junior Teacher's College (Education Science), 2009(1):98-101. 